\title{
Research on Optimization Paths of Modern Commerce Circulation Industry in China in the "13th Five Year Plan"Period
}

\author{
Sijing He \\ Yunnan College of Business Management, Kunming, 650106, China
}

\begin{abstract}
Commerce circulation is a link between production and consumption. It is one of the most important signs to measure the speed of economic development of a region or state. China has entered the construction period of "13th Five-Year Plan". In the new stage, we should clarify the development foundation and the existing problems of China's modern trade circulation industry and put forward the corresponding countermeasures for the development of China's modern commerce circulation industry to provide decision-making references.

Keywords:commerce circulation industry, optimization paths, 13th Five Year Plan

\section{Development foundation of commerce circulation industry in China}

China's circulationindustry has maintained the rapid development in the "12th Five-Year Plan" period under the correct leadership of CPC Central Committee and the State Council and the joint efforts of various departments and regions. It accelerates the pace of transformation and upgrades the coordinated development of urban and rural areas, significantly improve the level of modernization, significantly improve the business environment, in order to cope with the complex economic situation at home and abroad, and made important contribution to promote the healthy development of the national economy. Overall size continues to expand. During the "12th Five-Year Plan" period, the total retail sales of social consumer goods has increased by $13.8 \%$ each year,
\end{abstract}


reaching 30 trillion and 100 billion Yuan in 2015. Domestic circulation effectively stimulates and supports the national economic and social development. The actions of "Internet plus circulation" actively implement the plan for electronic commerce, demonstration enterprises, demonstration bases, demonstration city construction and promote coordinated development of ecommerce and logistics. Modern service industry comprehensive pilot accelerated the process of circulation modernization. Cloud computing, big data, networking, mobile Internet, supply chain and other advanced technology and management model to promote the application. Rapid development of crossborder e-commerce, overseas warehouse construction steadily. Positive results have been achieved in the way of trade in the market. Internal and external trade integration level increased significantly. The reform of the circulation system of comprehensive development pilot has achieved positive progress, and the dividends of streamlining administration and delegating power has gradually presented.

\section{Existing problems of commerce circulation industry in China}

\subsection{Low supply level}

China's commercial circulation modernization development process is slow. China's wholesale and retail, post and telecommunications industry, transportation industry, after years of development, is gradually moving towards maturity and perfection. But the market is still at a low level, the lack of ecommerce, online shopping and other new formats appear good soil, and in the era of knowledge economy, these industries will play a very important role. The main reason is that the new state of survival of the transportation and storage of goods and other aspects of the lack of safety, accuracy and convenience; commercial organizations to invest in the warehouse. However, the purchase of transportation equipment is not the economy; logistics system and social problems, is the knowledge economy brings to the circulation industry higher requirements. Although China has large stores, chain stores, convenience stores and other new formats, but China really on the level of the retail industry is one of the few; although there is a certain degree of development of supply chain operation in our country, we still lack the settled and joined famous enterprises at home and abroad.

\subsection{Insufficient information construction}

Compared with the traditional commercial circulation, modern commercial circulation along with the economic and social transformation process from material production oriented to the development and utilization of information resources and create value, relates to the social and economic life of the perplexing social system, specifically, including the producer to all end user connection process, in addition to flow, logistics also includes the circulation and information related to the capital circulation, the whole process of market 
circulation. Carrying out good information construction is the foundation and premise of building a modern trade center and it is the basic way to strengthen the function of the commercial center and to realize the circulation modernization. But compared with the large trade circulation enterprises, China's commercial circulation enterprises in the current capital turnover rate, enterprise inventory, logistics distribution costs and enterprise information level, and many other aspects, there is a big gap. At present, China's circulation industry from the overall situation, the basic information construction of most enterprises is still at a low level in the development and utilization of single product management, supply chain management, information resources management and circulation modernization requires the existence of a large gap, especially small and medium enterprises, the ubiquitous computing machine management rate is still very low, restricted the development of electronic commerce in china.

\subsection{Backward logistics development}

On one hand, the enterprise lacks the rational understanding of logistics management. The logistics market has not yet formed. The theory and concept of modern logistics has not yet been popularized in the production and circulation enterprises in our country. The logistics concept is old and self-closed, and the phenomenon of self - circulation is relatively common. On the other hand, the city's logistics enterprises still remain in the transport business. The highway freight transportation enterprise generally has the grade is not high, the scale is small, the function is single, the structure is not reasonable. It is difficult to form the scale benefit. In particular, the disorderly competition in the market is more serious, it is difficult to adapt to the current development of the logistics industry. At present, most of the logistics enterprises in our country can only provide single or segmented logistics services, logistics services mainly for warehousing, transportation, transportation and urban distribution. The operation is still dominated by hand. Specialized logistics service has just started.The logistics industry concentration is low, but the logistics service demand is high degree of dispersion, which caused the low demand of China's logistics suppliers. Logistics practitioners' cultural quality is generally not high, and middle and senior logistics personnel training mechanism has not yet formed.

\section{Optimization paths of modern commerce circulation industry in the "13th Five Year Plan" period}

\subsection{Improve supply level}

We make use of the role of the bridge between production and consumption, feedback market information and demand changes in a timely manner, to promote the demand for fixed production and supply and demand matching, improve the supply structure of the adaptability and flexibility of demand changes. Continue to strengthen agricultural super docking, actively carry out the commercial Internet and reduce the cost of circulation of agricultural products. To strengthen 
the construction of agricultural products supply base, and promote the production of agricultural products without pollution, green, organic products. The integrated use of information to guide, procurement, transportation, cross regional reserve, import organization, limited supply in accordance with the law, including expropriation of basic necessities of life, establish emergency mechanism, strengthen emergency ability. Actively develop new technologies and new artificial intelligence services, the use of the Internet platform to promote remote detection and diagnosis, operation and maintenance, technical support, after-sales service and other services for the development of new formats. To guide the construction of large commercial facilities such as shopping centers, and to encourage the comprehensive utilization of idle circulation facilities. Support for cross regional agricultural products cold chain logistics facilities and public welfare of agricultural products wholesale market construction, improve the primary origin key agricultural products classification, comprehensive processing and distribution, packaging warehousing, cold chain logistics, product traceability and other infrastructure. We guide the upgrading of agricultural products wholesale market.

\subsection{Strengthen informatization construction}

Support the circulation enterprises to strengthen information technology, and promote mobile Internet, cloud computing, big data, networking, virtual reality, artificial intelligence and block chain technology innovation and application in the field of circulation. Encourage circulation enterprises to apply modern management technologies. To strengthen the application of big data in market operation monitoring analysis and forecast early warning, improve the pertinence and effectiveness of market regulation and public information service. Accelerate the application of new information technology in the business field, to promote the transformation of the digital store. To encourage the country to information technology to foster a batch of multi-function, multi format wisdom commercial district based on the construction of a number of online and offline interaction in the district intelligence experience has influence and driving force of the country. Establish a cloud platform for business public services to promote the construction of business information services across the country, to achieve departmental, regional business data exchange system, to achieve the sharing of information. Guide the circulation enterprises to integrate and open data, construct the government and social interaction of information collection, sharing and application mechanism. Make full use of big data technology, improve market operation monitoring and risk early warning, and timely release relevant information to the community, reasonable guide market expectations, and promote supply and demand matching.

\subsection{Promote logistics service}

Continue to carry out e-commerce in rural comprehensive demonstration, the implementation of the rural electricity supplier million excellence programs in rural areas, to create electricity supplier, electricity supplier service station (point) 
to speed up the construction, improve the rural logistics system and improve the proportion of online sales of agricultural products, agricultural products, industrial products to open channels to the countryside. Improve agricultural circulation system. Promote the construction of public welfare agricultural products market system, the construction of a number of public welfare of the backbone of agricultural wholesale markets and regional agricultural wholesale market. Strengthen the construction of the circulation system of agricultural products; foster the circulation of the main body. Promote the formation of a reasonable layout, smooth flow, safe and efficient distribution of agricultural products throughout the country. Overall planning of urban and rural infrastructure construction, and guide the circulation enterprises to extend the service network in rural areas, improve the utilization efficiency of circulation facilities and the level of business services. Accelerate the development of modern logistics industry, and actively build business logistics center. Speed up logistics personnel training, training to create a number of familiar with the logistics business, with interdisciplinary comprehensive capacity of logistics management personnel and professional and technical personnel.

\section{Conclusion}

With the development of market economy in our country, the status of the commerce circulation industry is becoming more and more important in the national economy. The bi-directional communication function of the commerce circulation industry is significant whether in the industrial structure adjustment or in the urban and rural integration development. Enhancing the supply level, strengtheninginformatization construction and improving the logistics service are the essentialpaths to optimize the commerce circulation industry in the " 13 th Five-Year Plan"period in China.

\section{References}

[1]Song Ze, Seek for the New Innovative Development and New Breakthroughs forCommerce Circulation Industry in the"13th Five Year Plan"Period, China Business and Market, 30(1), pp. 10-16, 2016

[2]Zhu Heliang, Ye Meng, An Empirical Research on the Relationship between Outward ForeignDirect Investment and Circulation Industry Development in China, China Business and Market, 30(12), pp. 11-18, 2016

[3]Li Wengui, Development Countermeasures of Commercial Circulation Industry in Chinaunder New Urbanization, Reformation \& Strategy, 32(10), pp. 114-117, 2016

[4]Zhang Yimo, Transformation of Development Mode of China's Commercial Trade and Circulation Industry:Insight from Foreign Experience, Logistics Technology, 36(5), pp. 41-44, 2016. 